\title{
STRATEGI PEMASARAN OBAT HEWAN SATWA UNGGUL BLITAR (Studi Kasus Di Desa Sanankulon Kecamatan Sanankulon Kabupaten Blitar)
}

\author{
Imam Faozi ${ }^{1)}$, Errythrina Vinnifera Arnyke $^{2)}$ \\ ${ }^{1)}$ Mahasiswa Program Studi Ilmu Ternak Fakultas Peternakan \\ ${ }^{2)}$ Dosen Program Studi Ilmu Ternak Fakultas Peternakan \\ Universitas Islam Balitar \\ Jl. Majapahit No. 04 Kota Blitar
}

\begin{abstract}
The purpose of this study is to examine the marketing mix strategy that has been applied by the company in its business development, to analyze the internal and external environment condition faced by PT Satwa Unggul, to formulate the best alternative marketing strategy of PT Satwa Unggul by considering the company environment to be able to compete in the market. The data collected are primary and secondary data that are qualitative. The research method used in this study is primary data obtained from recording and direct interviews with leaders, employees, and customers. Secondary data is obtained from the report where the company jemen and literature in the form of library materials taken from previous research. The marketing mix strategy being carried out by the company concerning the product strategy (brand awareness on the brand), pricing strategy (discounted price), distribution strategy (three distribution patterns), and promotion strategy (animal inspection and free extension services) can assessed to have successfully accommodate the needs of customers with various facilities and company benefits. Based on internal environmental analysis with Descriptive Analysis can be seen that PT Satwa Unggul has a strong internal position. This means the company has been able to use its strengths and overcome its weaknesses quite well. Company's strengths include: affordable prices, good product quality, specialized workforces, sales with personal selling, and sales targets for large farmers. While the weakness of the company in the form: strong influence of leadership, capital limitations, delay in delivery time, no exclusive contract with customers, and the absence of $\mathrm{R} \& \mathrm{D}$ activities. Based on the analysis of the external environment with Descriptive Analysis, it can be seen that PT Satwa Unggul also has a strong external position, because it has been able to take advantage of opportunities and can handle the threat quite well .
\end{abstract}

\section{PENDAHULUAN}

Pengembangan subsektor peternakan merupakan bagian dari pembangunan pertanian yang tidak terpisahkan dari pembangunan nasional. Salah satu pembangunan di subsektor peternakan yang pada saat ini sedang digiatkan adalah pemenuhan gizi masyarakat yang berasal dari protein hewani. Protein tersebut dapat diperoleh dari daging. Daging merupakan produk peternakan yang banyak disukai oleh masyarakat, karena daging banyak mengandung gizi yang dibutuhkan oleh tubuh, seperti protein hewani, air, mineral, energi dan vitamin.

Ternak yang mengandung gizi dan dapat bermanfaat bagi manusia tentunya harus memiliki kualitas gizi yang baik. Ternak yang baik memiliki ciri-ciri, antara lain tidak pucat, warna merah segar, daging berisi dan tidak berbau. Kelayakan daging yang dikonsumsi harus diperhatikan, baik dilihat dari kandungan gizinya atau aman tidaknya daging itu dikonsumsi oleh masyarakat. Hal tersebut dilakukan untuk menghindari penularan penyakit berbahaya seperti antraks pada sapi ataupun flu burung yang menyerang unggas. 
Meningkatnya populasi ternak khususnya unggas menjadi alasan utama berdirinya perusahaan yang bergerak di bidang obat hewan. Untuk menghadapi persaingan yang ketat, peneliti menganalisis pengaruh personal selling danpromosi penjualan terhadap besarnya penjualan yang telah ada dan menganalisis relevansi strategi yang telah dijalankan dan berusaha merumuskan strategi promosi apa yang paling efektif untuk diterapkan perusahaan agar mampu bersaing dipasar.Hasil penelitian tersebut menunjukkan bahwa promosi penjualan dan personal selling berpengaruh nyata terhadap penjualan dengan nilai $\mathrm{R}$ sebesar97.8 persen. Persentase tersebut diestimasi dengan analisis berganda. Kesimpulan dari penelitian tersebut menunjukkan bahwa strategi promosi yang telah dan tengah dijalankan perusahaan dinilai masih cukup relevan dan perlu dikembangkan lagi dengan berbagai cara, yaitu : kemitraan non-integrated, diskon pembelian, kupon (voucher) dan meningkatkan kualitas personal selling dengan mengadakan pelatihan kepada para karyawan dan sales marketingnya.

Taufiq (2003) melakukan penelitian yang berjudul "Pola Penentuan Ternak Unggas Lokal Unggulan di Tiga Desa yang Berbeda Bioklimatnya di Kabupaten Cianjur". Penelitian tersebut dilatar belakangi oleh berkembangnyaternak unggas lokal yang belum diberdayakan secara maksimal. Faktor Bioklimat memiliki pengaruh yang kuat dalam perkembangan unggas di tempat yang berbeda. Berdasarkan hasil penelitian tersebut, dapat disimpulkan bahwa terdapat perbedaan pola pemeliharaan di tiga wilayah $(\mathrm{p}<0.05)$, dan ternak ayam berada pada kuadran yang berbeda untuk tiap wilayahnya sehingga membutuhkan strategi pemasaran yang berbeda di tiap wilayahnya.

\section{MATERI DAN METODE}

\section{Metode Pengumpulan Data}

Data yang dikumpulkan adalah data primer dan sekunder yang bersifat kualitatif. Data primer diperoleh dari pencatatan dan wawancara langsung dengan pimpinan, karyawan, dan pelanggan. Untuk kelengkapan data, peneliti menggunakan kuisioner yang ditujukan kepada salah seorang dewan direksi beserta dua orang stafnya yang memiliki kompetensi untuk memenuhi informasi tentang kekuatan dan kelemahan perusahaan. Pengisian kuisioner ditujukan kepada tiga orang dengan jabatan, sebagai berikut : Direktur Marketing dan Operasional, Koordinator Penjualan dan Distribusi, dan Menajer HRD untuk melihat kondisi internal perusahaan.Data sekunder diperoleh dari laporan mana jemen perusahaan dan literatur-literatur yang berupa bahan pustaka yang diambil dari penelitian sebelumnya. Tabel1. Jenis Data dan Sumber Data Penelitian

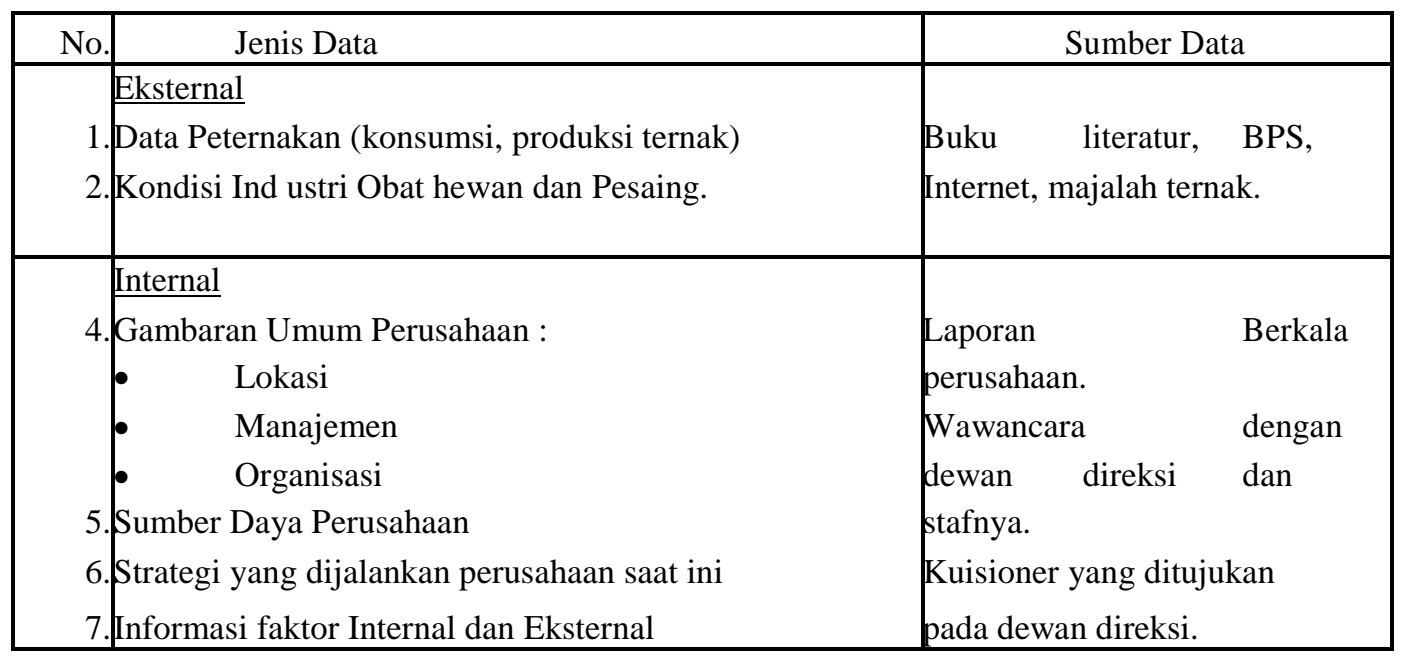




\section{Hasil Pengamatan Dan Pembahasan}

Tingkat persaingan sebuah perusahaan dipengaruhi oleh struktur pasarindustrinya. Struktur pasar terbagi dalam tiga kelompok besar, yaitu : pasarpersaingan sempurna, pasar monopoli, dan pasar persaingan tidak sempurna yang terbagi atas pasar monopolistik dan oligopoli. Ketiga struktur pasar tersebut memiliki kondisi bersaing yang berbeda, sehingga setiap perusahaan harus menerapkan strategi pemasaran terbaik untuk menghadapi persaingan.

Industri obat hewan termasuk kedalam industri yang memiliki struktur pasar persaingan tidak sempurna, yaitu pasar oligopoli. Hal tersebut dapat dilihat dari ciri-ciri industrinya, yaitu :

1. Perusahaan memiliki posisi sebagai price maker. Perusahaan tidak menerapkan harga jual berdasarkan keseimbangan suplai dan demand yang terbentuk di pasar, namun penerapan harga jual produk ditentukan sesuai dengan biaya produksi, biaya variabel dan mark up.

2. Hambatan masuk dalam industri obat hewan cukup besar besar. Hambatan alamiah berkaitan dengan skala dan cakupan ekonomi dalam produksi (teknologi dan tingkat standarisasi dalam sterilisasi obat) serta biaya pemasaran dengan modal yang cukup besar. Hambatan ciptaan perusahaan dapat dibuat dengan mengembangkan merek- merek yang bersaing, iklan citra merek yang gencar dan menetapkan harga predator jika pendatang baru masuk. Pendatang baru yang potensial dapat masuk dan bertahan dengan menekan laba dan biaya tertanamnya (sunk cost).

3. Kondisi persaingan yang ketat dalam pasar obat hewan dengan kondisi banyaknya penjual obat hewan, sedangkan jumlah peternakan sebagai sasaran pemasaran cenderung sama dari tahun ketahun.

4. Struktur pasar oligopoli akan menampakkan laba ekonomi dalam jangka panjang. PT Satwa unggul sebagai produsen obat hewan telah berproduksi selama 15 tahun dan berhasil meraih pangsa pasar di atas dua persen. Semakin lama umur perusahaan, akan semakin kuat posisi perusahaan tersebut. Hal tersebut terjadi karena konsumen telah mengenal produk dengan baik, sehingga dapat terjalin kerjasama dalam jangka waktu yang lama.

Kondisi perusahaan saat ini telah dinilai cukup baik oleh dewan direksi. Perusahaan berharap dapat bertahan (survive) dalam waktu yang lama dalam industri obat hewan. Perusahaan juga menginginkan adanya ekspansi dalan pemasaran obat hewan ke wilayah lain dengan banyak mendirikan anak cabang perusahaan di wilayah Sulawesi dan Kalimantan pedalaman.

\section{Strategi Pemasaran Satwa Unggul}

Pemasaran merupakan salah satu kegiatan perusahaan untuk mempertahankan keberadaan produknya, terutama dalam keadaan permintaan pasar yang tidak stabil. Dalam situasi persaingan, perusahaan harus menerapkan strategi pemasaran yang dinamis dan disesuaikan dengan kondisi pasar yang ada. PT Satwa Unggul melakukan strategi pemasaran dengan bauran pemasaran (marketing mix), yang mengkombinasikan variabel produk, harga, distribusi dan promosi.

\section{Strategi Produk}

Strategi produk yang dilakukan oleh perusahaan meliputi strategi keputusan atribut produk, kemasan dan pelabelan produk. Strategi ini lebih banyak berhubungan dengan pengelolaan produk sebelum maupun pada saat produk yang bersangkutan berada dipasar. Strategi brand image untuk merek produk digunakan oleh perusahaan untuk memberi ingatan 
pada konsumen bahwa obat-obat tersebut berasal dari perusahaan .

Dalam menghasilkan kualitas produk yang baik, produsen memperhatikan beberapa faktor berikut:

1) Bahan Baku

Bahan baku yang digunakan oleh perusahaan adalah zat kimia obat. Komposisisnya adalah Vitamin A, B1, C, D, dan K serta tambahan kandungan zat sesuai dengan manfaat yang dinginkan. Kualitas bahan baku selalu menjadi perhatian perusahaan, karena produk yang baik dapat terbentuk dari kualitas bahan baku yang baik. Mayoritas bahan baku harus diimpor untuk menjaga kualitas produk untuk memenuhi standar internasional.

Produk merupakan unsur penting dalam sebuah industri. Kualitas obat yang baik dapat menjadi keunggulan sebuah perusahaan. PT Satwa Unggul memiliki produk yang memiliki kualitas yang baik. Hal tersebut sesuai dengan pendapat beberapa konsumen yang ditemui oleh peneliti di perusahaan ketika sedang melakukan pemesanan obat hewan. Hal tersebut dapat dilihat pada reaksi obat yang cepat dalam mengobati unggas. Untuk pemeliharaan, obat dicampurkan dengan pakanunggas agar unggas mendapatkan masukan gizi dan vitamin yang berguna untuk pertumbuhannya. Kualitas obat dapat tetap terjaga karena obat dibuat dari bahan impor yang memenuhi standar kesehatan obat hewan internasional.

\section{2) Kemasan}

Produk dipasarkan dalam beberapa kemasan, yaitu : tube, botol, sachet, karton, kantong, dan drum. Pelabelan pada kemasan terlihat dengan jelas. Nama produk dan nama perusahaan tertulis dominan pada tampilan depan kemasan untuk menghindari pemalsuan produk. Kemasan bergambar ayam sebagai lambang obat untuk unggas.

Berdasarkan wawancara yang dilakukan terhadap beberapa konsumen, dapat dilihat bahwa PT Satwa Unggul memiliki kemasan yang cukup baik. Hal tersebut dapat dilihat pada bungkus kemasan dengan warna, gambar, dan tulisan yang menarik. Produk dikemas secara steril dan harus segera digunakan ketika kemasan dibuka untuk menjaga obat agar tidak kontak langsung dengan udara bebas. Komposisi dan kandungan obat dapat terlihat jelas pada label kemasan. Cara pemakaian dan tanggal kadaluarsa obat secara berkala dikontrol oleh dokter hewan yang ditugaskan oleh perusahaan.

\section{Strategi Harga}

Strategi harga merupakan strategi yang penting bagi manajemen. PT Satwa Unggul menetapkan harga jual produk berdasarkan biaya produksi ditambah dengan profit yang disesuaikan dengan harga jual produk sejenis dari perusahaan lain. Harga yang dijual relatif sama dengan produsen lain, tapi perusahaan dapat memadukan strategi harga dengan strategi promosi denganmemberikan potongan harga, jika pelanggan membeli dengan cara tunai atau membeli dalam jumlah besar. Tingkat perbandingan beberapa produk perusahaan berdasarkan perbandingan harganya dengan perusahaan kompetitor dapat dilihat pada Tabel 2

Tabel 2. Perbandingan Harga Jual Produk PT Satwa Unggul dengan Kompetitornya Tahun 2015

\begin{tabular}{|l|c|l|c|l|c|c|c|}
\hline \multicolumn{2}{|c|}{ PT Satwa Unggul } & \multicolumn{2}{c|}{$\begin{array}{c}\text { Kompetitor A } \\
\text { (PT Agro Makmur) }\end{array}$} & \multicolumn{2}{c|}{$\begin{array}{c}\text { Kompetitor B } \\
\text { (PT Medion) }\end{array}$} & \multicolumn{2}{c|}{$\begin{array}{c}\text { Kompetitor C } \\
\text { (PT Mensana) }\end{array}$} \\
\hline $\begin{array}{c}\text { Nama } \\
\text { Produk }\end{array}$ & $\begin{array}{c}\text { Harga } \\
\text { (Rp) } \\
\text { /sachet }\end{array}$ & $\begin{array}{c}\text { Nama } \\
\text { Produk }\end{array}$ & $\begin{array}{c}\text { Harga } \\
\text { (Rp) } \\
\text { /sachet }\end{array}$ & $\begin{array}{c}\text { Nama } \\
\text { Produk }\end{array}$ & $\begin{array}{c}\text { Harga } \\
\text { (Rp) } \\
\text { /sachet }\end{array}$ & $\begin{array}{c}\text { Nama } \\
\text { Produk }\end{array}$ & $\begin{array}{c}\text { Harga } \\
\text { (Rp) } \\
\text { /sachet }\end{array}$ \\
\hline Boster & 10750 & K-Kablet & 8300 & Aminovit & 9800 & GG-Stim & 10400 \\
Digeston & 14000 & Albenda & 13000 & Coxy & 10000 & Vermipzol & 18500 \\
Dinabro & 14000 & Chictonik & 13000 & C-Ekitor & 15000 & Fortevit & 14500 \\
Dnamycin & 33250 & Enroflo & 37950 & Stimulant & 38500 & Erysuprim & 35200 \\
Dinazol & 21500 & Koleridin & 26500 & Ampicol & 25200 & Hipralona & 39600
\end{tabular}




\begin{tabular}{|l|l|l|r|r|r|l|r|} 
Disvektor & 10725 & Kututox & 7000 & Antisep & 11000 & Formades \\
Vetmacol & 18500 & Koksidex & 34400 & Doctril & 21000 & Duoko & 16800 \\
\hline
\end{tabular}

Sumber : PT Satwa Unggul 2015

Berdasarkan Tabel 2, dapat dilihat bahwa beberapa produk PT Satwa Unggul dijual jauh lebih murah dibandingkan dengan produk sejenis dengan nama yang berbeda dari kompetitornya. Akan tetapi, walaupun nama produk berbeda, namun fungsi obat tersebut sama. Produk Dnamycin merupakan obat infeksi anti CRD dan SNOT dijual dengan harga lebih murah dengan harga yang ditetapkan oleh kompetitornya. Obat anti kolera dan coli dengan merek Dinazol dijual perusahaan dengan harga jauh lebih murah dibandingkan dengan obat sejenis lainnya. Obat antibiotika antisiklina dengan merek Vetmacol dijual perusahaan dengan harga relatif lebih murah.

Namun demikian, beberapa produk perusahaan dijual dengan harga sedikit lebih mahal sebagai transfer profit karena produk tersebut tingkat permintaannya tidak terlalu tinggi atau bahkan obat dijual dengan harga lebih mahal karenamemiliki kualitas yang sangat baik, seperti multivitamin dengan merek Boster yang dijual sedikit lebih mahal jika dibandingkan dengan produk sejenis.

Hal tersebut sesuai dengan pernyataan beberapa konsumen yang ditemui oleh peneliti, yang menyatakan bahwa PT Satwa Unggul memiliki harga jual produk yang cukup baik. Harga jual beberapa produk cukup kompetitif, sedikit lebih murah jika dibandingkan dengan produk sejenis yang diproduksi oleh perusahaan lain.

Konsumen memiliki bargaining position yang kuat dibandingkan dengan produsen. Hal tersebut disadari karena jumlah produsen obat hewan yang banyak jika dibandingkan dengan jumlah peternak sebagai konsumen relatif tetap dari tahun ke tahun.

\section{Strategi Distribusi}

Strategi distribusi dapat digunakan untuk melihat konsistensi perusahaan dalam sebuah industri. Semakin banyak produknya beredar, semakin mudah konsumen mendapatkannya, maka semakin mudah merek produk tersebut masuk kedalam ingatan konsumen. PT Satwa Unggul menggunakan penyebaran sales penjualan dan dokter hewan kepeternakan-peternakan terdekat untukmemberikan penyuluhan, melakukan pendekatan individu dalam menyebarkan produknya.

Pemasaran dengan pendekatan pribadi (personal selling) menjadi keunggulan bagi perusahaan. Hal tersebut direspon secara positif oleh konsumen, karena konsumen dapat memperoleh informasi yang jelas mengenai penggunaan obat hewan. Sales sudah cukup menguasai materi tentang produk dan mengetahui sedikitnya tentang perkembangan peternakan di Indonesia. Sales penjualan selalumencari peternakan-peternakan lain yang belum ia datangi untuk memasarkan produk perusahaan. Sales dilengkapi dengan fasilitas kendaraan bermotor roda dua untuk membantu pekerjaannya.

Namun demikian, perusahaan juga memiliki kelemahan dalam hal keterlambatan waktu pengiriman (time lag). Hal tersebut dapat dilihat dari waktu pengantaran yang sering terlambat. Hal tersebut dirasa sangat merugikan konsumen, karena mereka seringkali harus menunggu barang pesanannya. Hal itu sudah disadari oleh pihak perusahaan sebagai suatu kelalaian karena proses transportasi yang sering bermasalah, baik dalam hal penyediaan stok gudang cabang yang terlalu sedikit maupun waktu pesan yang terkadang bersamaan dengan pesanan pihak lain.

Saluran distribusi memegang peranan penting dalam penyebaran produk.Memilih saluran distribusi yang tepat dapat membant $\mathrm{u}$ meningkatkan volume penjualan. Menyadari 
pentingnya hal tersebut, PT Satwa Unggul menggunakan tiga jenis saluran distribusi untuk mengakomodasi kebutuhan obat hewan dalam negeri. Pola distribusi pertama langsung dipasarkan ke peternak. Pola ini merupakan keunggulan perusahaan, karena dapat berinteraksi la ngsung dengan peternak. Pola kedua dan ketiga melalui pelantara, namun perusahaan tetap memperhitungkan tingkat keefektifannya. Ketiga pola distribusi tersebut menggunakan sistem personal selling dalam mendistribusikan obat hewan dari perusahaan kepada konsumen tingkat pertama yang digambarkan dengan tanda panah. Perusahaan bertanggung jawab terhadap pendistribusian hanya sampai konsumen tingkat pertama, sedangkan proses distribusi selanjutnya menjaditanggung jawab pihak distributor obat hewan. Gambar 4 menunjukkan saluran distribusi yang dilakukan oleh perusahaan.

\section{Kesimpulan}

Berdasarkan hasil penelitian, maka dapat diambil kesimpulan sebagai berikut:

1. PT Satwa Unggul memproduksi obat hewan dalam tiga kelompok besar yaitu : Parmaceutik, Kelompok Biologi, Kelompok Premix dalam beberapa bentuk, yaitu : tablet, bubuk obat, dan larutan. Produknya tersebut dijual dalam berbagai kemasan, yaitu : kemasan, botol, tube, sachet, karton, jerigen, dan drum untuk jumlah besar. Untuk produk obat yang berbentuk bubuk, kemasannya berupa sachet, plastik, karton, dan drum. Sedangkan untuk obat yang berupa cairan atau larutan, perusahaan mengemasnya dalam botol, jerigen, dan drum.

2. Strategi bauran pemasaran yang tengah dilakukan oleh perusahaan yang menyangkut strategi produk (berupa brand awareness atas merek), strategi harga (berupa potongan harga), strategi distribusi (berupa tiga pola distribusi), dan strategi promosi (berupa pemeriksaan hewan dan layanan penyuluhan gratis) dapat dinilai telah berhasil mengakomodasi kebutuhan pelanggan dengan berbagai fasilitas dan keunggulan perusahaan.

3. Berdasarkan analisis lingkungan internal dengan Analisis Deskriptif dapat dilihat bahwa PT Satwa Unggul memiliki posisi internal yang kuat. Hal ini berarti perusahaan telah mampu menggunakan kekuatan dan mengatasi kelemahannya dengan cukup baik. Kekuatan yang dimiliki oleh perusahaan berupa : harga yang terjangkau, kualitas produk baik, tenaga kerja terspesialisasi, penjualan dengan personal selling, dan sasaran penjualan pada peternak besar. Sedangkan kelemahan perusahaan berupa : kuatnya pengaruh pimpinan, keterbatasan modal, keterlambatan waktu pengiriman, tidak ada kontrak eksklusif dengan pelanggan, dan tidak adanya kegiatan litbang. Berdasarkan analisis lingkungan eksternal dengan Analisis Deskriptif, dapat dilihat bahwa PT Satwa Unggul juga memiliki posisi eksternal yang kuat, karena telah mampu memanfaatkan peluang dan dapat mengatasi ancaman dengan cukup baik. Peluang yang dimiliki perusahaan berupa : peningkatan konsumsi daging nasional, cukup tersedia angkatan kerja, kemajuan teknologi, perilaku animal care, dan hambatan masuk industri tinggi. Sedangkan ancaman yang masuk berupa : kekuatan tawar- menawar pemasok dan pembeli cukup kuat, meningkatnya laju inflasi, fluktuasi nilai tukar rupiah, dan tingginya tingkat persaingan.

\section{Saran}

Berdasarkan hasil penelitian, didapat beberapa hal yang harus diperhatikan dalam perkembangan industri obat hewan. Maka peneliti ingin memberikan saran dan masukan sebagai bahan pertimbangan untuk perbaikan dimasa yang akan datang. Saran tersebut diantaranya : 
1. Perusahaan sebaiknya mempertahankan keunggulan strategi pemasaran yang dijalankan berupa personal selling dan strategi promosi. Personal selling sebagai strategi penguat dari strategi promosi iklan yang selama ini diterapkan oleh perusahaan. Perusahaan juga memperbaiki kelemahannya dalam keterlambatan waktu pengiriman (time lag) untuk menambah kepercayaan konsumen kepada perusahaan dengan cara : memuat stok barang dalam jumlah besar pada seluruh anak cabang perusahaan dan memberikan garansi bonus barang jika pengantaran lebih dari $2 \times 24$ jam.

2. Perusahaan dapat menggunakan promosi dengan mendirikan posko-posko atau balai-balai konsultasi dan layanan peternakan disekitar wilayah peternakan yang dilengkapi dengan pemasangan atribut dan merek obat untuk menciptakan ingatan akan merek pada konsumen.

PT Satwa Unggul sebagai produsen obat hewan sebaiknya melakukan riset secara berkala mengenai perilaku konsumen obat hewan agar strategi yang diterapkan benar-benar sesuai dengan kondisi pasar.

\section{Daftar Pustaka}

Alfredo. 2005. Analisis Strategi Pemasaran Meubel Berdikari Furniture. Skripsi Sarjana. Departemen Sosial Ekonomi Pertanian, Fakultas Pertanian, Institut Pertanian Bogor. Bogor.

Badan Pusat Statistik. http://www.bps.go.id 2004. Statistik Indonesia. Jakarta. 2004. Statistik 60 Tahun Indonesia Merdeka. Jakarta. 2004. Statistik Konsumsi Daging Indonesia.

Jakarta. Cahyono, Bambang Tri. 1996. Manajemen Pemasaran. IPWI. Jakarta.

David, Fred R. 2002. Manajemen Strategis. Alih Bahasa Alexander Sindoro. Prenhallindo. Jakarta.

Direktorat Jendral Peternakan. 2004. BahanStatistik Peternakan.

Engel, James F, dkk. 1994. Perilaku Konsumen. Alih Bahasa Budiyanto. Binarupa Aksara. Jakarta.

Ikhsan, Benil. 2005. Peran Sektor Peternakan Unggas dan Dampak Flu BurungTerhadap Kinerja Sektor Ekonomi di Indonesia. Skripsi Sarjana.Departemen Sosial Ekonomi Pertanian, Fakultas Pertanian, Institut Pertanian Bogor. Bogor.

Ilmawan, Taufik. 2003. Pola Penentuan Ternak Unggas Lokal Unggulan di Tiga Desa yang Berbeda Bio-klimatnya di Kabupaten Cianjur. Departemen Ilmu Produksi Ternak, Fakultas Peternakan, Institut Pertanian Bogor. Bogor.

Kotler, Philip. 2000. Manajemen Pemasaran. Alih Bahasa Hendra Teguh,dkk. Prenhallindo. Jakarta. 
Porter, Michael E. 1994. Keunggulan Bersaing. Binarupa Aksara.

Jakarta. Suharno, Bambang. 2005. Data Bisnis Peternakan. Gita Pustaka. Jakarta.

Suhendi, Endi. 1997. Analisis Strategi Promosi Obat Hewan. Tesis Magister (yang tidak dipublikasikan), Sekolah Tinggi Ilmu Ekonomi IPWI. Jakarta.

Sumawihardja, Surachman. 1991. Intisari Manajemen Pemasaran. Rosda. Bandung. 